\title{
Conjugated linoleic acid (CLA) during gestation and lactation does not alter sow performance or body weight gain and adiposity in progeny
}

\author{
Sylvia P. POULOS ${ }^{\mathrm{a}, \mathrm{b}}$, Michael J. AZAIN ${ }^{\mathrm{c}}$, Gary J. HAUSMAN ${ }^{\mathrm{a}, \mathrm{b} *}$ \\ a Department of Foods and Nutrition, The University of Georgia, Athens, GA 30602, USA \\ ${ }^{b}$ US Department of Agriculture, Agricultural Research Service, Animal Physiology Research Unit, \\ Athens, GA 30605, USA \\ ${ }^{\mathrm{c}}$ Department of Animal and Dairy Sciences, The University of Georgia, Athens, GA 30602, USA
}

(Received 8 December 2003; accepted 15 July 2004)

\begin{abstract}
The objective of this study was to determine the long-term effects of conjugated linoleic acid (CLA) in pigs exposed to CLA during fetal and neonatal growth. Sows were fed a diet with $0.83 \%$ soy oil or $0.83 \%$ CLA-60 containing $60 \%$ active CLA isomers from either d 40 (group 1; CON $n=8$, CLA $n=6$ ) or $\mathrm{d} 75$ (group 2; CON $n=8$, CLA $n=8$ ) of gestation through weaning on $\mathrm{d} 28$. Within group 1 , one male and one female piglet per litter (CON $n=6, \operatorname{CLA} n=5)$ were sacrificed within 24 hours of birth (d 0) and body weights recorded. Semitendinosus muscle, subcutaneous adipose tissue and organs, including heart, liver, lung, kidney, brain were weighed and tissue samples were frozen. Two average weight barrows and two gilts per litter were weaned and fed standard diets without added CLA until market weight. CLA did not alter sow's feed intake during gestation or lactation, body weight or backfat thickness, and litter size and weight at birth $(P>0.05)$. CLA decreased newborn pig heart, but not backfat or semitendinosus muscle weights relative to their body weights (d 0). CLA decreased pre-weaning weight in selected piglets but this was not maintained post-weaning. CLA decreased total milk fat by $17 \%(P<0.01)$ and resulted in an increase in the relative amount of saturated fatty acids and a decrease in the relative amount of unsaturated fatty acids in milk on d 21 of lactation $(P<0.05)$. Decreases in growth rates until d 14 may be due to decreased fat in sow's milk since growth rate and body weight of selected progeny did not differ post-weaning. Serum from newborn CLA pigs suppressed relative preadipocyte number and did not change lipid filling in stromal-vascular cell cultures. The response to this serum was greater in females than in males $\left(P_{\text {Diet }}=0.04 ; P_{\text {Diet }} \times\right.$ Gender $\left.=0.04\right)$. Thus, there do not seem to be any long-term effects on growth and body composition of market weight pigs given $0.5 \%$ CLA through weaning that would be beneficial in a production scheme.
\end{abstract}

conjugated linoleic acid / gestation / lactation / porcine / adipose

\footnotetext{
* Corresponding author: ghausman@saa.ars.usda.gov

Present address: 950 College Station Road, Athens, GA 30605, USA.
} 
Résumé - La distribution d'acide linoléique conjugué (CLA) pendant la gestation et la lactation n'affecte ni les performances des truies ni le gain de poids corporel et l'adiposité de leurs porcelets. L'objectif de cette étude était de déterminer les effets à long terme de l'acide linoléique conjugué (CLA) chez les porcs recevant du CLA pendant leur croissance fotale et néonatale. Des truies ont été alimentées avec un régime à base d'huile de soja $(0,83 \%, \mathrm{CON})$ ou de CLA- $60(0,83 \%$, CLA) contenant $60 \%$ des isomères actifs de CLA, soit à partir du $40^{\mathrm{e}}$ jour de gestation (groupe 1 ; CON $n=8$, CLA $n=6$ ) soit au 75e jour de gestation (groupe 2 ; CON $n=8$, CLA $n=8$ ) jusqu'au sevrage (28 jours après la naissance). Dans le groupe 1, un porcelet mâle et un porcelet femelle par portée (CON $n=6$, CLA $n=5)$ ont été sacrifiés à moins de 24 heures de la naissance (d 0$)$ et le poids corporel des animaux enregistré. Le muscle semitendinosus, le tissu adipeux sous-cutané et les organes, comprenant le coeur, le foie, le poumon, les reins ainsi que le cerveau ont été pesés, et des échantillons de tissu ont été congelés. Deux porcelets mâles castrés de poids moyens et deux jeunes truies par portée ont été sevrés et alimentés avec des régimes standards sans supplémentation de CLA jusqu'au poids d'abattage du marché. Le CLA n'a pas modifié la quantité d'aliments ingérée par la truie pendant la gestation ou la lactation, le poids corporel ou l'épaisseur du gras dorsal, et la taille et le poids de la portée à la naissance $(P>0,05)$. Le CLA a diminué le poids du coeur du nouveauné, mais pas le poids du gras dorsal ou du muscle semitendinosus par rapport au poids corporel (d 0 ). Le CLA a diminué le poids pré-sevrage des porcelets mais cet effet ne s'est pas maintenu en postsevrage. La matière grasse totale du lait a été diminuée par CLA de $17 \%(P<0,01)$, ce qui a eu pour conséquence une augmentation relative de la quantité d'acides gras saturés et une diminution de la quantité relative d'acides gras insaturés du lait le $21^{\mathrm{e}}$ jour de lactation $(P<0,05)$. La diminution de la vitesse de croissance jusqu'à 14 jours pourrait être due à la faible teneur en lipides du lait des truies puisque la vitesse de croissance et le poids corporel des porcelets n'ont pas différé en postsevrage. Le sérum des porcelets nouveau-nés soumis au CLA a diminué le nombre relatif de préadipocytes et n'a pas modifié le stockage de lipides dans les cellules stromales vasculaires en culture. Ces observations ont d'ailleurs été plus marquées chez les femelles que chez les mâles $\left(P_{\text {Diet }}=\right.$ 0,$04 ; P_{\text {Diet }} \times$ Gender $\left.=0,04\right)$. Il ne semble pas y avoir d'effets bénéfiques à long terme sur la croissance et la composition corporelle au poids habituel d'abattage chez les porcs ayant reçu $0,5 \%$ de CLA jusqu'au sevrage.

acide linoléique conjugué / gestation / lactation / porc / tissu adipeux

\section{INTRODUCTION}

Conjugated linoleic acid (CLA), a group of positional and geometric isomers of linoleic acid, has many reported biological activities which alter body composition. CLA reportedly improves body composition by decreasing adipose tissue deposition, increasing leanness, growth, and meat quality [1]. Studies using CLA in rodents have consistently shown more drastic and more consistent suppression of adipose tissue growth and enhanced lean tissue growth than those in larger animals and humans. Although studies in gilts have shown no effect on live body weights [3] cellular changes may be occurring, as was seen in rats which also showed no changes in body weight [24]. Our recent study in rats showed that $0.5 \%$ CLA fed during gestation and lactation has long-term effects on bone, muscle and adipose growth, although the greatest changes in body composition were evident in animals fed CLA from weaning into adulthood [24]. In vitro studies using 3T3-L1 cells have shown CLA supplementation decreases proliferation and inhibits lipid accumulation [4, 29]. Fat cell development in pigs begins between $45 \mathrm{~d}$ and 75 $\mathrm{d}$ of fetal life [13]. Therefore, the objective of this study was to test the hypothesis that CLA decreases preadipocyte proliferation, as was seen in cultured 3T3-L1 cells, and decreases the propensity to deposit fat. In addition, we examined the effects of CLA on sow performance, such as weight loss during lactation. To determine if CLA feeding causes changes in circulating factors in serum that would alter adipocyte development we evaluated changes in preadipocyte cell number and lipid filling in primary porcine stromal-vascular cell cultures. 
Table I. Diet composition.

\begin{tabular}{|c|c|c|}
\hline & Gestation $^{\mathrm{a}}$ & Lactation $^{\mathrm{a}}$ \\
\hline Corn & 65.5 & 52.95 \\
\hline Soybean meal $49 \%$ & 11.15 & 20.5 \\
\hline Soy Hulls & 10.0 & 10.0 \\
\hline Alfalfa meal & 5.0 & 5.0 \\
\hline Animal Fat & 3.9 & 6.4 \\
\hline Dicalcium phosphate & 2.70 & 2.80 \\
\hline Limestone & 0.55 & 0.40 \\
\hline Salt & 0.35 & 0.35 \\
\hline $\mathrm{KCl}$ & 0 & 0.75 \\
\hline Lysine-HCl & 0.20 & 0.20 \\
\hline Vitamin Premix ${ }^{b}$ & 0.25 & 0.25 \\
\hline Trace Mineral Premix ${ }^{c}$ & 0.15 & 0.15 \\
\hline Sow Vitamins ${ }^{\mathrm{d}}$ & 0.25 & 0.25 \\
\hline \multicolumn{3}{|l|}{ Calculated Analysis } \\
\hline Crude Protein $(\%)$ & 13.00 & 16.54 \\
\hline Lysine $(\%)$ & 0.78 & 1.04 \\
\hline $\operatorname{ME}\left(\mathrm{MJ} \cdot \mathrm{kg}^{-1}\right)$ & 13.67 & 14.08 \\
\hline $\mathrm{Ca}(\%)$ & 0.90 & 0.90 \\
\hline $\mathrm{P}(\%)$ & 0.75 & 0.80 \\
\hline
\end{tabular}

${ }^{a}$ CLA-60 (Conlinco, Detroit Lakes, MN) was added to the standard gestation or lactation diet at the rate of $8.3 \mathrm{~g} \cdot \mathrm{kg}^{-1}$ of diet to achieve $0.50 \%$ CLA. The same amount $\left(8.3 \mathrm{~g} \cdot \mathrm{kg}^{-1}\right)$ of soy oil was added to the diet fed to the control group. The CLA-60 supplement provided $6.38 \%$ palmitic acid, $0.09 \%$ palmitoleic acid, $4.37 \%$ stearic acid, $21.25 \%$ oleic acid, $9.31 \%$ linoleic acid, $21.35 \%$ cis- 9 , trans-11 CLA, $25.72 \%$ trans- 10 , cis-12 CLA and $11.51 \%$ unknown fatty acids as determined by gas chromatography.

$\mathrm{b}$ The vitamin premix (Animal Science Products, Nacogdoches, TX) provided the following per kilogram of complete diet: 11000 IU vitamin A, 1650 IU vitamin D, 44 IU vitamin E, $4.4 \mathrm{mg}$ vitamin K, $9.9 \mathrm{mg}$ riboflavin, $55 \mathrm{mg}$ niacin, $33 \mathrm{mg}$ pantothenic acid, $44 \mu \mathrm{g}$ vitamin $\mathrm{B}_{12}$.

${ }^{\mathrm{c}}$ The trace mineral premix (Animal Science Products, Nacogdoches, TX) provided the following per kilogram of complete diet: $165 \mathrm{mg}$ iron, $16.5 \mathrm{mg}$ copper, $39.6 \mathrm{mg}$ manganese, $165 \mathrm{mg}$ zinc, $0.3 \mathrm{mg}$ iodine, and $0.3 \mathrm{mg}$ selenium.

$\mathrm{d}$ The sow vitamin pack provided the following per kilogram of complete diet: $551 \mathrm{mg}$ choline, $0.22 \mathrm{mg}$ biotin, $1.65 \mathrm{mg}$ folic acid and $15.2 \mathrm{mg}$ pyridoxine.

\section{MATERIALS AND METHODS}

\subsection{Animals and diet}

Parity matched, gestating sows $(\mathrm{CON}$, 3.6; CLA, 4.1; Pooled SEM, 0.6; $P=0.46$; Yorkshire $\times$ Hampshire $\times$ Landrace) in the University of Georgia herd were fed corn and soybean meal based diets (Tab. I) that were supplemented with either $0.83 \%$ soy oil (CON) or $0.83 \%$ CLA-60, (CLA, Conlinco, Detroit Lakes, MN, USA). Sows in two farrowing groups began diet treatment on either $\mathrm{d} 40$ (group $1 ; \mathrm{CON} n=8, \operatorname{CLA} n=$ 6) or d 75 (group $2 ; \mathrm{CON} n=8$, CLA $n=8$ ) of gestation through d 28 of lactation. As expected, CON diets contained low amounts of the cis- 9 , trans- 11 and the trans10 , cis-12 CLA isomers $\left(0.2-0.3 \mathrm{mg} \cdot \mathrm{g}^{-1}\right)$ while the CLA supplement diets contained 5-6 mg.g ${ }^{-1}$ CLA. The minimal amount of CLA present in the CON supplemented diet is likely due to the animal fat in the diet. Sows were limit fed $2.0 \mathrm{~kg} \cdot \mathrm{d}^{-1}$ during gestation and fed ad libitum during lactation. The day of farrowing was designated as $\mathrm{d} 0$. 
Within $24 \mathrm{~h}$ of birth, sow, pig, and litter weights were recorded. Backfat thickness at the tenth rib was determined on sows on $\mathrm{d} 0$ and at weaning ( $28 \mathrm{~d}$ ) using a LeanMeater (Renco, Minneapolis, MN, USA). Milk samples from each sow were collected from several teats without removing piglets and without the use of oxytocin on d 21 (groups 1 and 2) of lactation. Milk samples were frozen at $-20{ }^{\circ} \mathrm{C}$ for determination of milk fat content and fatty acid profile. Litter records including number of pigs per litter and litter weight at birth, d 7, d 21 and weaning were maintained.

Between 8 and $16 \mathrm{~h}$ of birth, one male and one female piglet from CON fed $(n=6)$ and CLA fed $(n=5)$ litters in group 1 were sacrificed to determine the effects of CLA during gestation. Piglets were injected intraperitoneally with $30 \mathrm{mg} \cdot \mathrm{kg}^{-1}$ 5-bromo2'-deoxyuridine (BrdU, Boehringer Mannheim Corp., Indianapolis, IN, USA) to determine rates of cell proliferation. Piglets were sacrificed one hour later using intraperitoneal injections of sodium pentobarbitol. Several litters were excluded ( $\mathrm{CON} n=2$; CLA $n=3$ ) because pigs could not be collected between the 8-16 h time window used in this study. Brain, heart, lung, liver, kidney, semitendinosus muscles, and subcutaneous adipose tissue collected from the piglet's back were weighed and samples were snap frozen and stored at $-70{ }^{\circ} \mathrm{C}$ for further analysis. Blood was collected via cardiac puncture, serum collected and frozen at $-70{ }^{\circ} \mathrm{C}$. All other piglets remained with sows until weaning (d 28) and had free access to the sow's diet but were not offered creep feed. At weaning (d 28) 2 barrows and 2 gilts per litter that were closest to the average weight of the litter were selected and blood samples were collected. After weaning these selected pigs were fed diets that met or exceeded the NRC requirements for growing pigs and were maintained until they were approximately $110 \mathrm{~kg}$ body weight. At this time, images of the loin muscle and backfat at the tenth rib taken with an Aloka 633 ultrasound unit (Corometrics Medical Systems, Wallingford, CT) were used to determine backfat depth and loin muscle area. Previous studies have validated the use of ultrasound measures of loin area and backfat thickness [28]. Backfat thickness, loin eye area, percent lean, and days to $113 \mathrm{~kg}$ were determined using National Swine Improvement Federation Guidelines [20].

All animal procedures were conducted in compliance with established guidelines from The University of Georgia Institutional Animal Care and Use Committee.

\subsection{Serum assays}

Blood was collected and kept at $4{ }^{\circ} \mathrm{C}$ for $12 \mathrm{~h}$ before centrifugation at $1800 \times g$ for $20 \mathrm{~min}$. Serum was stored at $-70^{\circ} \mathrm{C}$ until assayed. Serum leptin concentrations were determined using a multi-species RIA kit as previously described [25] (Linco Research, Inc., St. Charles, MO, USA). Assay sensitivity was $0.1 \mathrm{ng}$ per tube. Insulin-like growth factor-1 (IGF-1) concentrations of serum were determined via RIA using rabbit IGF-1 antiserum UBK487 [15] (distributed by the National Hormone and Pituitary Program, Bethesda, MD, USA) and recombinant human IGF-1 (Amgen Biologicals, Thousand Oaks, CA, USA) as the standard. The specific radioactivity of the ${ }^{125}$ I-IGF-1 (Dupont NEN Research Product, Boston, MA, USA) was $345 \mu \mathrm{Ci} \times \mu \mathrm{g}^{-1}$. Triacylglycerol (352; INT 336; Sigma Diagnostics, St. Louis, MO, USA) and blood urea nitrogen (BUN, 535-A; Sigma Diagnostics, St. Louis, MO, USA) concentrations of serum were determined via colorimetric assays.

\subsection{Tissue and milk composition}

Dry matter and lipid content of adipose, cerebellum, heart, kidney, liver, lung, and semitendinosus muscle tissues were determined. Approximately $1-1.5 \mathrm{~g}$ of each tissue was frozen and dried under vacuum in a freeze dryer (Labconco, Kansas City, MO). Lipids were extracted from freeze-dried tissues using chloroform and methanol 
$(1: 2 \mathrm{v} / \mathrm{v})$ followed by chloroform and $1 \mathrm{M}$ $\mathrm{KCl}(1: 1 \mathrm{v} / \mathrm{v})$.

Fatty acid composition of milk and tissue samples was determined with gas chromatography using with a flame ionization detector (Shimadzu, Model 14A, Columbia, MD, USA). Approximately $1-1.5 \mathrm{~g}$ of lung, liver, kidney, heart and $0.5 \mathrm{~g}$ each of cerebellar and adipose tissue from each piglet and $1 \mathrm{~mL}$ of sow's milk were frozen at $-20^{\circ} \mathrm{C}$ until fatty acid composition was determined. Fatty acids were saponified and methylated as previously described [24]. Fatty acid methyl esters were separated on a Supelcowax-10 fused capillary column $(60 \mathrm{~m} \times 0.53 \mathrm{~mm}, 0.50 \mu \mathrm{m}$ film thickness; Supelco, Bellefonte, PA, USA) under isothermal conditions at $240{ }^{\circ} \mathrm{C}$. Sample size was $0.5 \mu \mathrm{L}$ and helium was the carrier gas. Peaks were identified by comparison of retention times of known standards, including pure samples of CLA isomers (Matreya, Pleasant Gap, PA, USA). CLA isomers separated were cis-9, trans-11 CLA and 10-trans, 12-cis CLA. Quantification was corrected for recovery of the internal standard and is based on the reference standard.

\subsection{Immunoblotting}

Subcutaneous adipose tissue, kidney, liver, and lung tissues form newborn pigs were homogenized and lysed with $1 \mathrm{X}$ lysis buffer containing $60 \mathrm{nmo} \cdot \mathrm{L}^{-1}$ Tris ( $\mathrm{pH}$ 6.8) and $10 \mathrm{~g} \cdot \mathrm{L}^{-1} \mathrm{SDS}$. The lysate was centrifuged $(12000 \times g, 10 \mathrm{~min})$ and the protein concentration was determined using the Bio-Rad protein assay (Bio-Rad Laboratories, Hercules, CA, USA). One hundred micrograms of protein from adipose tissue was diluted in SDS-sample buffer, boiled for $5 \mathrm{~min}$, and placed on ice for one min. This was followed by electrophoresis and separation of adipose tissue proteins on $16 \mathrm{~cm}, 12.5 \%$, SDS-polyacrylamide gels at $100 \mathrm{~V}$ and a one $\mathrm{h}$ transfer, at $100 \mathrm{~V}$, to Immobilon-P protein sequencing membrane (Millipore Corp., Bedford, MA, USA). One hundred micrograms of protein from kidney, lung, and liver tissue was placed directly onto Immobilon-P protein sequencing membrane (Millipore Corp., Bedford, MA, USA) using a Minifold II slot blot system (Schleicher and Schuell, Keene, NH, USA). Membranes were blocked for nonspecific binding sites using a $50 \mathrm{~g} \cdot \mathrm{L}^{-1}$ nonfat powdered milk solution for one $h$. Adipose tissue proteins were then probed for CCAAT/ enhancer binding protein $\alpha$ and CCAAT/ enhancer binding protein $\delta(\mathrm{C} / \mathrm{EBP} \alpha$, cata$\log \#$ sc-61; C/EBPS, catalog \# sc-151; Santa Cruz Biotechnology, Santa Cruz, CA, USA) for one $h$ followed by a one $h$ incubation with horseradish polypeptidase conjugated secondary anti-rabbit immunoglobulin G (Amersham, Arlington Heights, IL, USA). Both $\mathrm{C} / \mathrm{EBP} \alpha$ and $\mathrm{C} / \mathrm{EBP} \delta$ are rabbit polyclonal antibodies corresponding to rat proteins and are mouse, rat, and human reactive. Antibody dilutions were $1 / 500$, $1 / 500$, and $1 / 4000$ respectively. Membranes containing kidney, liver, and lung tissue were probed for anti-bromodeoxyuridine (1/1000 BrdU; Affinity Bioreagents Inc., Golden, CO, USA) for one $\mathrm{h}$ followed by a one $\mathrm{h}$ incubation with horseradish polypeptidase conjugated secondary anti-mouse immunoglobulin G (1/5000; Amersham; Arlington Heights, IL, USA). Immunoreactive polypeptides were visualized using ECL chemiluminescence (Amersham, Piscataway, NJ, USA). Protein band density was determined using a densitometer to compare protein amounts (Molecular Dynamics, Sunnyvale, CA, USA). To ensure the specificity of these results, blots were exposed to the secondary antibody alone and used as negative controls.

\subsection{Cell culture}

Bioactivity of serum from CLA fed piglets was determined by evaluating changes in primary stromal-vascular cell cultures from $75 \mathrm{~d}$ old fetal pigs $(n=3)$. Primary stromal-vascular cells were isolated as previously described [14]. Cells were resuspended in Dulbecco's Modified Eagle's Medium (DMEM) supplemented with 5\% serum from each of 22 piglets $(12 \mathrm{CON}$, 
10 CLA) and $1 \times 10^{5}$ cells were plated on each of three $35 \mathrm{~mm}$ culture dishes. Fresh media containing $5 \%$ pig serum was added $3 \mathrm{~d}$ post plating thus cultures were exposed to serum from each pig for $6 \mathrm{~d}$. Six d post plating (D6), immunocytochemistry for AD-3, a preadipocyte cell surface antibody, followed by Oil-Red-O and hematoxylin staining was performed. Briefly, culture dishes were rinsed in $0.01 \mathrm{M}$ PBS, fixed in $4 \%$ paraformaldehyde, rinsed, incubated with AD-3 antibody (1/50 dilution), rinsed, incubated with an ExtrAvidin peroxidase staining kit as instructed (Sigma-Aldrich Co. St. Louis, MO, USA), incubated with AEC color substrate, and rinsed. Dishes were then stained with a $60 \%$ Oil-Red-O solution for $10 \mathrm{~min}$, rinsed, stained with hematoxylin for $2 \mathrm{~min}$, rinsed, covered, and mounted with glycerol gelatin (SigmaAldrich Co. St Louis, MO, USA). Three photomicrographs of each culture dish at a 10X magnification were used to determine total cell number, preadipocyte cell number, and lipid containing cell number. Computer assisted image analysis (Image-Pro Plus, Media Cybernetics, Inc., Silver Spring, MD, USA) was used to quantify lipid droplet area.

\subsection{Statistical analysis}

Data were analyzed by the PROC GLM procedure in SAS. Values are reported as least square mean \pm SEM. In most cases, sow or litter was considered the experimental unit. The effects of diet on sow and litter performance and sow milk fatty acid profile were determined using the PROC GLM procedure in SAS with the main effects of diet, group and their interaction. The significance of effects of maternal diet on progeny was tested using a model with the main effects of diet, litter nested within diet and group. Pig nested within litter and diet was used as the error term.

\section{RESULTS AND DISCUSSION}

Improved body composition or performance is a way of increasing the cost-effec- tive production of highly desirable meats. A number of studies investigating the effectiveness of CLA supplemented diets in improving swine production have shown variable responses in lean tissue mass and adipose accumulation $[1,9,12,32]$. Reports in swine indicate gender [31] and age [32] influence CLA's apparent effects more than genotype [33] and that $5 \mathrm{~g}$ CLA per kg diet was an effective dose for reducing lipid accretion and subcutaneous fat thickness [1]. Thus, the goal of this study was to determine if CLA supplementation of a sow's diet during critical periods of fetal adipose tissue development would induce changes resulting in leaner animals with higher consumer appeal. We chose to include CLA in maternal diets prior to adipocyte differentiation and during the early phase of endocrine responsiveness of developing adipocytes [13].

Diet treatments beginning on $\mathrm{d} 40$ (group 1) or on d 75 (group 2) of gestation did not affect sow or litter performance thus results of these two groups have been combined and summarized in Table II. As previously reported in pigs and rats $[3,24]$ there was no significant difference in body weight or litter weight of progeny at birth. CLA tended to decrease body weight at $\mathrm{d} 7 \mathrm{com}$ pared to control pigs selected to remain in the study until market weight. This difference in weight was significant by $\mathrm{d} 14$ (CON-F, $4.51 \pm 0.20 \mathrm{~kg}$; CON-M, $4.43 \pm$ $0.20 \mathrm{~kg}$; CLA-F, $3.88 \pm 0.27 \mathrm{~kg}$; CLA-M, $\left.3.87 \pm 0.27 \mathrm{~kg} ; P_{\text {Diet }}<0.05\right)$ but was not maintained post-weaning. The effect of suppressed pre-weaning growth is likely due to the sample of pigs selected to remain in the study as the weights of all piglets did not differ among treatment groups. In pigs sampled from group 1, maternal CLA consumption beginning on $\mathrm{d} 40$ of gestation decreased relative heart weights $\left(P_{\text {Diet }}=\right.$ $0.006, P_{\text {Diet } \times \text { Gender }}=0.09 ; \mathrm{g}$ tissue per $100 \mathrm{~g}$ body weight) and tended to decrease relative kidney weight $\left(P_{\text {Diet }}=0.09\right)$ in newborn pigs while male piglets tended to have smaller lungs $\left(P_{\text {Diet }}=0.07\right)$ compared to females (Tab. III). Percent dry matter and 
Table II. Effect of dietary CLA on sow and litter performance ${ }^{1,2}$.

\begin{tabular}{ccccc}
\hline & $\begin{array}{c}\text { CON } \\
(n=16)\end{array}$ & $\begin{array}{c}\text { CLA } \\
(n=14)\end{array}$ & $\begin{array}{c}\text { Pooled } \\
\text { SEM }\end{array}$ & $\begin{array}{c}P \text {-Value } \\
\text { Diet }\end{array}$ \\
\hline Sow Body Weight (kg) & & & & \\
Pre-farrowing & 244.0 & 246.7 & 8.9 & 0.84 \\
Weaning & 218.7 & 224.5 & 9.9 & 0.69 \\
Change & 25.3 & 22.2 & 4.1 & 0.59
\end{tabular}

Sow Feed Intake (during

lactation, $\mathrm{d} 0-\mathrm{d} 28)$

$\begin{array}{lcccc}\text { Total }(\mathrm{kg}) & 226.1 & 200.2 & 15.0 & 0.23 \\ \mathrm{ADF}\left(\mathrm{kg} \cdot \mathrm{d}^{-1}\right) & 8.0 & 7.2 & 0.5 & 0.26 \\ \mathrm{ADF} / \mathrm{litter} \text { gain } & 3.3 & 3.2 & 0.1 & 0.59\end{array}$

Sow Backfat (mm)

$\begin{array}{lcccc}\text { Pre-farrowing } & 23.2 & 22.3 & 1.1 & 0.57 \\ \text { Weaning } & 22.2 & 20.1 & 1.1 & 0.17 \\ \text { Change } & 1.0 & 2.2 & 0.8 & 0.27\end{array}$

Number of Pigs

$\begin{array}{lcccc}\text { Live at Birth } & 12.3 & 10.8 & 0.6 & 0.11 \\ \text { Dead at Birth } & 0.9 & 1.1 & 0.4 & 0.77 \\ \text { Weaned } & 10.8 & 9.8 & 0.6 & 0.25\end{array}$

Average Pig Weight $(\mathrm{kg})$

$\begin{array}{lcccc}\text { Birth } & 1.53 & 1.53 & 0.05 & 0.99 \\ \text { Day 7 } & 2.73 & 2.66 & 0.14 & 0.75 \\ \text { Day 14 } & 4.56 & 4.41 & 0.20 & 0.62 \\ \text { Weaning } & 8.03 & 8.06 & 0.38 & 0.96 \\ \text { Age at Weaning } & 28.1 & 27.6 & 0.6 & 0.58 \\ \text { Survival (\%) } & 89.0 & 90.7 & 2.6 & 0.66\end{array}$

${ }^{1}$ Results are least squares means for two consecutive farrowing groups of 7-8 sows per group on each diet. Group 1 was started on test diets on day 40 of gestation, while group 2 was started on diets on day 75 of gestation. There were no differences in response to diet between groups so the data were pooled. Differences were considered significant if $P<0.05$.

2 Piglets taken from sows within $24 \mathrm{~h}$ were not included in calculations for the number of pigs live at birth, dead at birth, number weaned, or \% survival.

percent lipid of semitendinosus muscle, liver, heart, lung and kidneys were not influenced by maternal CLA consumption $(P>0.05)$.

Reports using cell culture systems suggest CLA may alter proliferation and differentiation of 3T3-L1 adipocytes [4, 17, 29]. Human preadipocytes cultured in the presence of trans-10, cis-12 isomer had decreased differentiation and peroxisome proliferator-activated receptor (PPAR $\gamma$ ) expression, whereas those cultured with the cis-9, trans-11 isomer had increased PPAR $\gamma$ expression [5]. However, treatment with the cis-9, trans-11 or the trans-10, cis-12 isomers did not change PPAR $\gamma$ expression in cultures of primary porcine stromal-vascular cells [19]. In vivo studies have shown dietary CLA increases C/EBP $\alpha$ protein [24] and the expression of several metabolic genes in adipose tissue in swine [30]. Because of these conflicting reports, proliferation and differentiation in adipose tissue and primary cultured cells was assessed in this study. Several markers of adipose tissue development were not influenced by CLA including adipose tissue weight, cell proliferation as measured by BrdU incorporation, 
Table III. Relative organ weights (g tissue per $100 \mathrm{~g} \mathrm{BW}$ ) of newborn male and female pigs from sows fed conjugated linoleic acid (CLA) beginning on day 40 of gestation (group 1) $)^{1,2}$.

\begin{tabular}{lcccccccc}
\hline & CON-F & CLA-F & CON-M & CLA-M & Pooled & \multicolumn{4}{c}{$P$-Value } \\
\cline { 8 - 10 } \cline { 7 - 9 } & $(n=6)$ & $(n=5)$ & $(n=6)$ & $(n=5)$ & SEM & Diet & Sex & Diet $\times$ Gender \\
\hline Body weight $(\mathrm{g})$ & 1713 & 1623 & 1708 & 1683 & 116 & 0.69 & 0.85 & 0.82 \\
g.100 g $\mathrm{g}^{-1}$ body weight & & & & & & & & \\
Heart & 0.76 & 0.60 & 0.71 & 0.66 & 0.03 & 0.006 & 0.94 & 0.09 \\
Liver & 2.60 & 2.43 & 2.55 & 2.44 & 0.16 & 0.43 & 0.91 & 0.86 \\
Kidney & 0.41 & 0.35 & 0.39 & 0.32 & 0.02 & 0.09 & 0.13 & 0.64 \\
Adipose & 0.21 & 0.34 & 0.24 & 0.23 & 0.05 & 0.28 & 0.39 & 0.15 \\
Brain & 2.30 & 1.96 & 2.00 & 1.95 & 0.14 & 0.28 & 0.38 & 0.43 \\
Semitendinosus & 0.20 & 0.22 & 0.17 & 0.20 & 0.02 & 0.25 & 0.26 & 0.68 \\
Muscle & & & & & & & & \\
Lung & 1.45 & 1.20 & 1.49 & 1.41 & 0.09 & 0.16 & 0.07 & 0.32 \\
\hline
\end{tabular}

${ }^{1}$ Values are least square means. Differences were considered significant if $P<0.05$. Abbreviations: control female, CON-F; CLA female, CLA-F; control male, CON-M; and CLA male, CLA-M.

${ }^{2}$ Organ weights are expressed relative to warm carcass weight.

and cell differentiation as measured by $\mathrm{C} /$ $\mathrm{EBP} \alpha$ and $\mathrm{C} / \mathrm{EBP} \delta$ protein expression. $\mathrm{C} /$ $\mathrm{EBP} \alpha$ and $\mathrm{C} / \mathrm{EBP} \delta$ expression in adipose tissue from newborn CLA pigs relative to CON pigs was not influenced by maternal CLA consumption or gender $(P>0.05)$. There was also no influence of CLA intake on BrdU incorporation in kidney, liver, or lung tissue from newborn pigs, suggesting there was no difference $(P>0.05)$ in rates of cell replication at birth. The possibility that CLA alters circulating factors was tested by exploring the effects of serum from these pigs on primary stromal-vascular cultures from fetal adipose tissue. Studies of stromal-vascular cells isolated from $75 \mathrm{~d}$ old fetuses grown in serum collected from newborn CLA pigs showed that CLA suppressed relative preadipocyte number though no differences in lipid filling were observed (Tab. IV). The response to this serum was greater in females than in males $\left(P_{\text {Diet }}=\right.$ $\left.0.04 ; P_{\text {Diet } \times \text { Gender }}=0.04\right)$. These results show that serum from CLA exposed pigs affects cell growth by decreasing relative preadipocyte number. This suggests CLA may affect the nonadipogenic cells present in adipose tissue and may alter circulating adipogenic factors. Dietary CLA has also been shown to decrease serum concentrations of several factors with key roles in adipogenesis including triacylglycerol, leptin, non-esterified fatty acids, and glucose in rats [26]. We observed changes in serum triacylglycerol which may be an avenue of circulating factors affecting tissue growth. Maternal CLA consumption beginning on day 40 of gestation did not alter serum blood urea nitrogen, insulin-like growth factor 1 , or leptin concentrations in newborn pigs (Tab. IV). Studies of cultured cells exposed to a combination of both CLA and linoleic acid have shown linoleic acid can partly restore triacylglycerol accumulation in 3T3-L1 cells [6] suggesting cells require the presence of several fatty acids for appropriate development. Thus, changes in the types and amounts of fatty acids present in tissue may play a role in CLAs affects on tissue growth.

In the present study, CLA was not consistently incorporated into tissues from 
Table IV. Serum factor concentrations and adipogenic bioactivity from newborn male and female pigs of sow's fed CLA beginning on day 40 of gestation (group 1). Adipogenic activity was assessed by $5 \%$ serum inclusion in primary porcine stromal-vascular cell culture medium ${ }^{1}$.

\begin{tabular}{|c|c|c|c|c|c|c|c|c|}
\hline & \multirow{2}{*}{$\begin{array}{l}\text { CON-F } \\
(n=6)\end{array}$} & \multirow{2}{*}{$\begin{array}{l}\text { CLA-F } \\
(n=5)\end{array}$} & \multirow{2}{*}{$\begin{array}{l}\text { CON-M } \\
(n=6)\end{array}$} & \multirow{2}{*}{$\begin{array}{l}\text { CLA-M } \\
(n=5)\end{array}$} & \multirow{2}{*}{$\begin{array}{l}\text { Pooled } \\
\text { SEM }\end{array}$} & \multicolumn{3}{|c|}{$P$-Value } \\
\hline & & & & & & Diet & Gender & Diet $\times$ Gender \\
\hline \multicolumn{9}{|l|}{ Serum Factor } \\
\hline $\begin{array}{l}\text { Triacylglycerol } \\
\left(\mathrm{mmol} \cdot \mathrm{L}^{-1}\right)\end{array}$ & 0.05 & 0.04 & 0.03 & 0.05 & 0.01 & 0.64 & 0.38 & 0.01 \\
\hline $\begin{array}{l}\text { Blood Urea Nitrogen } \\
\left(\mathrm{mmol} \cdot \mathrm{L}^{-1}\right)\end{array}$ & 6.91 & 4.99 & 4.70 & 3.92 & 0.78 & 0.17 & 0.10 & 0.55 \\
\hline $\begin{array}{l}\text { Insulin-like Growth } \\
\text { Factor } 1\left(\mu \mathrm{g} \cdot \mathrm{L}^{-1}\right)\end{array}$ & 24.37 & 28.73 & 45.34 & 22.18 & 8.77 & 0.30 & 0.42 & 0.13 \\
\hline Leptin $\left(\mu \mathrm{g} \cdot \mathrm{L}^{-1}\right)$ & 3.63 & 3.41 & 3.70 & 3.20 & 0.33 & 0.30 & 0.83 & 0.68 \\
\hline \multicolumn{9}{|l|}{ Serum Bioactivity } \\
\hline $\begin{array}{l}\text { Total cell number/ } \\
10 \mathrm{X} \text { microscopic } \\
\text { field }\end{array}$ & 768.0 & 1106.0 & 1015.7 & 858.7 & 124.6 & 0.59 & 0.73 & 0.26 \\
\hline $\begin{array}{l}\text { Preadipocytes } / 10 \mathrm{X} \\
\text { microscopic field }\end{array}$ & 19.0 & 14.9 & 17.4 & 12.0 & 2.7 & 0.10 & 0.47 & 0.35 \\
\hline $\begin{array}{l}\text { Adipocytes } / 10 \mathrm{X} \\
\text { microscopic field }\end{array}$ & 6.5 & 7.9 & 5.7 & 5.1 & 1.6 & 0.83 & 0.31 & 0.70 \\
\hline $\begin{array}{l}\text { Preadipocytes/Total } \\
\text { cell number }\end{array}$ & 3.0 & 1.6 & 1.9 & 1.5 & 0.4 & 0.04 & 0.13 & 0.04 \\
\hline $\begin{array}{l}\text { Adipocytes/Total cell } \\
\text { number }\end{array}$ & 0.8 & 0.6 & 0.6 & 0.5 & 0.1 & 0.46 & 0.16 & 0.44 \\
\hline $\begin{array}{l}\text { Lipid Area } \\
\text { (arbitrary units) }\end{array}$ & 109.9 & 122.0 & 116.0 & 116.0 & 5.9 & 0.31 & 0.92 & 0.57 \\
\hline
\end{tabular}

${ }^{1}$ Differences were considered significant if $P<0.05$. Abbreviations: control female, CON-F; CLA female, CLA-F; control male, CON-M; and CLA male, CLA-M.

newborn pigs from CLA fed sows (Tab. V). The failure to observe consistent changes in tissue CLA content of pigs sampled at birth leads one to question whether there is placental transfer. Heart, kidney, and adipose tissues did show changes in fatty acids but these patterns were not similar to those previously described in other animal models [7]. CLA accretion was observed in the kidneys and hearts of newborn pigs from CLA fed sow's indicating CLA did transfer across the placenta to fetal tissues. Interest- ingly, these were the tissues which showed differences in relative weight as relative heart weight and relative kidney weight tended to be decreased when compared to CON pigs. Fatty acid profiles from samples of cerebellum and lung from CLA pigs showed no significant differences when compared to tissues from CON pigs (data not shown). CLA has been shown to decrease $\Delta 9$ desaturase activity resulting in decreased 16:1 and 18:1 [30]. Changes in monounsaturated fatty acids were not consistently 
Table V. Effect of feeding conjugated linoleic acid (CLA) beginning on day 40 of gestation (group 1) on relative fatty acid composition of various tissues from newborn male and female pigs $1,2,3,4$.

\begin{tabular}{|c|c|c|c|c|c|c|c|c|c|}
\hline & & $14: 1$ & $16: 0$ & 16:1 & 18:0 & $18: 1$ & $\begin{array}{l}\text { cis-9, trans-11 } \\
\text { CLA }\end{array}$ & $\begin{array}{l}\text { 10-trans, } \\
\text { 12-cis CLA }\end{array}$ & $20: 4$ n-6 \\
\hline \multirow[t]{6}{*}{ Fat } & CON-F & 0.63 & 21.97 & 7.87 & 8.60 & 27.37 & 0.21 & 0.17 & 0.78 \\
\hline & CLA-F & 1.05 & 28.48 & 11.83 & 9.60 & 28.51 & 0.10 & 0.11 & 0.30 \\
\hline & CON-M & 0.78 & 21.20 & 22.37 & 8.46 & 22.96 & 0.23 & 0.21 & 0.34 \\
\hline & CLA-M & 1.11 & 26.87 & 9.83 & 8.46 & 27.84 & 0.28 & 0.28 & 0.71 \\
\hline & $\begin{array}{l}\text { Pooled } \\
\text { SEM }\end{array}$ & 0.20 & 1.98 & 5.02 & 1.10 & 1.73 & 0.06 & 0.05 & 0.28 \\
\hline & $P$-Value & \multicolumn{3}{|c|}{$\mathrm{D}=0.01$} & & & \multicolumn{3}{|c|}{$\mathrm{G}=0.05$} \\
\hline \multirow{6}{*}{ Kidney } & CON-F & 0.51 & 16.41 & 2.32 & 13.54 & 27.01 & 0.10 & 0.11 & 1.69 \\
\hline & CLA-F & 1.96 & 19.02 & 4.76 & 12.39 & 24.66 & 0.16 & 0.12 & 1.54 \\
\hline & CON-M & 0.79 & 16.84 & 3.95 & 12.97 & 25.78 & 0.03 & 0.07 & 1.71 \\
\hline & CLA-M & 1.63 & 18.78 & 4.00 & 11.95 & 25.58 & 0.24 & 0.19 & 1.66 \\
\hline & $\begin{array}{l}\text { Pooled } \\
\text { SEM }\end{array}$ & 0.81 & 2.03 & 1.17 & 0.51 & 1.03 & 0.05 & 0.04 & 0.09 \\
\hline & $P$-Value & & & & $\mathrm{D}=0.05$ & & $\mathrm{D}=0.01$ & & \\
\hline \multirow[t]{6}{*}{ Heart } & CON-F & 3.28 & 14.45 & 3.31 & 13.49 & 23.72 & 0.04 & 0.02 & 0.84 \\
\hline & CLA-F & 2.80 & 12.90 & 5.84 & 13.98 & 24.09 & 0.18 & 0.13 & 0.80 \\
\hline & CON-M & 4.76 & 14.73 & 3.71 & 12.73 & 23.79 & 0.08 & 0.03 & 0.76 \\
\hline & CLA-M & 0.72 & 12.30 & 2.95 & 16.18 & 26.57 & 0.05 & 0.05 & 0.86 \\
\hline & $\begin{array}{l}\text { Pooled } \\
\text { SEM }\end{array}$ & 0.92 & 1.09 & 1.37 & 0.70 & 1.06 & 0.03 & 0.03 & 0.03 \\
\hline & $P$-Value & $\mathrm{D}=0.02$ & & & $\begin{array}{c}D=0.01 \\
D \times G=0.05\end{array}$ & & $\mathrm{D} \times \mathrm{G}=0.02$ & $\mathrm{D}=0.02$ & $\mathrm{D} \times \mathrm{G}=0.03$ \\
\hline
\end{tabular}

1 Values are least square means for CON-F $(n=6), \operatorname{CLA}-\mathrm{F}(n=5), \operatorname{CON}-\mathrm{M}(n=6)$, and CLA-M $(n=5)$ pigs. Abbreviations: control female, CON-F; CLA female, CLA-F; control male, CON-M; and CLA male, CLA-M.

$2 \mathrm{~g}$ per $100 \mathrm{~g}$ total extractable saponafiable fatty acids.

3 The following fatty acids were included in statistical analysis but were excluded from this table: 14:0, 18:3, 20:0, 20:1, 20:4 n-3, 22:0, 20:5 n-3, 22:1, 24:0, 22:5.

${ }^{4} P$-value symbols: $\mathrm{D}$ represents a main effect of diet, $\mathrm{G}$ represents a main effect of gender, and $\mathrm{D} \times \mathrm{G}$ represents an interaction of diet and gender. Differences were considered significant if $P<0.05$.

observed among all tissues. Significant increases in saturated fatty acids were observed in several tissues including adipose tissue $\left(16: 0 ; P_{\text {Diet }}=0.01\right)$ and hearts $\left(18: 0, P_{\text {Diet }}=0.01, P_{\text {Diet } \times \text { Gender }}=0.05\right)$. CLA feeding also resulted in differences in polyunsaturated fatty acids. CLA accumulation in adipose, brain, and liver was not elevated due to maternal CLA consumption. It is possible that CLA increased energy availability for growing tissues after the onset of the study and, therefore, after much 
Table VI. Effect of dietary CLA on fatty acid composition of sow milk collected on d 21 from sows in groups 1 and $2^{1,2,3}$.

\begin{tabular}{lcccc}
\hline Fatty acid & $\begin{array}{c}\text { CON } \\
(n=11)\end{array}$ & $\begin{array}{c}\text { CLA } \\
(n=15)\end{array}$ & $\begin{array}{c}\text { Pooled } \\
\text { SEM }\end{array}$ & $P$-value \\
\hline $14: 0$ & 2.82 & 3.14 & 0.16 & $\mathrm{NS}$ \\
$16: 0$ & 28.76 & 30.07 & 1.01 & $\mathrm{NS}$ \\
$16: 1$ & 9.68 & 6.51 & 0.43 & 0.001 \\
$18: 0$ & 3.92 & 6.10 & 0.20 & 0.001 \\
$18: 1$ & 35.50 & 33.34 & 1.42 & $\mathrm{NS}$ \\
$18: 2$ & 17.04 & 17.10 & 0.48 & $\mathrm{NS}$ \\
$18: 3$ & 0.77 & 0.65 & 0.02 & 0.01 \\
cis-9, trans-11 CLA & 0.21 & 0.79 & 0.03 & 0.001 \\
trans-10, cis-12 CLA & 0.00 & 0.71 & 0.04 & 0.001 \\
Unknown & 1.29 & 1.59 & 0.08 & 0.01 \\
Total (mg-mL -1$)$ & 74.5 & 61.7 & 3.4 & 0.01 \\
Percent Composition: & & & & \\
$\quad$ Saturated & 35.49 & 39.31 & 1.1 & 0.02 \\
Mono-unsaturated & 45.18 & 39.85 & 1.1 & 0.002 \\
CLA total & 0.21 & 1.50 & 0.1 & 0.0001 \\
\hline
\end{tabular}

${ }^{1}$ Values are least square means.

${ }^{2}$ Results are expressed as g of each fatty acid per $100 \mathrm{~g}$ fatty acid.

${ }^{3}$ Differences were considered significant if $P<0.05$.

of the organ development has occurred. However, it is also possible that CLA is affecting organ development in the fetus as it has been shown to increase body weight and muscle mass independently of its effects on adipose tissue $[22,24]$. In contrast, CLA was elevated in milk samples collected on d 7 (not shown) and 21 of lactation.

CLA accumulation in tissue of postweaning animals appears to be markedly increased as compared to fetal animals [24]. After birth, maternal triacylglycerols are used for milk synthesis and are available to the newborn [16]. In the present study, maternal milk samples did show significantly higher amounts of CLA in CLA fed versus control fed sows which is similar to that reported by Bee [3]. Milk, collected from sows in both groups on d 21 of lactation, showed CLA incorporation into milk (Tab. VI) as determined by analysis of fatty acid composition. Total fat was decreased $17 \%(P<0.01)$ in milk from sows fed CLA (CON, $74.5 \mathrm{~g} \cdot \mathrm{L}^{-1}$; CLA, $\left.61.7 \mathrm{~g} \cdot \mathrm{L}^{-1}\right)$. On a percentage basis, feeding CLA resulted in an increase in the amount of saturated and a decrease in the amount of unsaturated fatty acids. There was some endogenous cis-9, trans-11 CLA but no trans-10, cis- 12 CLA detected in the milk of control sows. Feeding CLA increased the content of both isoforms of CLA in milk. Milk was collected from sows in group 1 on $\mathrm{d} 7$ of lactation as well and the profile was similar to that on d 21 (not shown). In our study milk samples also showed a marked suppression in total fat content though not as dramatic as the $\sim 50 \%$ decrease in milk fat content observed in dairy cattle [8]. Changes in the milk fat and the proportion of saturated and unsaturated fatty acids are similar to that noted for the effect of CLA on body fat stores and is consistent with the inhibition of porcine desaturase activity by CLA [30]. Previous work has shown that suppressing milk fat should induce growth suppression and decrease body weights [11]. It has been shown that the amount of saturated fatty 
Table VII. Pre- and post-weaning growth of selected male and female progeny of sows fed CLA during gestation and lactation $1,2,3$.

\begin{tabular}{|c|c|c|c|c|c|c|c|c|}
\hline & CON-F & CLA-F & CON-M & CLA-M & Pooled & & $P$-Val & alue \\
\hline & $(n=29)$ & $(n=23)$ & $(n=29)$ & $(n=23)$ & SEM & Diet & Gender & Diet $\times$ Gender \\
\hline Body Weight $(\mathrm{kg})$ & & & & & & & & \\
\hline Birth & 1.56 & 1.52 & 1.56 & 1.55 & 0.06 & NS & NS & NS \\
\hline Day 7 & 2.78 & 2.53 & 2.74 & 2.55 & 0.12 & 0.02 & NS & NS \\
\hline Weaning & 8.14 & 7.67 & 7.94 & 7.64 & 0.25 & NS & NS & NS \\
\hline Final & 105.4 & 101.3 & 114.3 & 113.3 & 2.3 & NS & 0.001 & NS \\
\hline Gain $\left(g \cdot d^{-1}\right)$ & & & & & & & & \\
\hline 0 -Wean & 242 & 228 & 234 & 223 & 8 & NS & NS & NS \\
\hline Wean-Final & 653 & 634 & 714 & 711 & 15 & NS & 0.001 & NS \\
\hline 0-Final & 595 & 570 & 639 & 635 & 11 & NS & 0.001 & NS \\
\hline Backfat Thickness (cm) & 2.12 & 2.15 & 2.83 & 2.56 & 0.10 & NS & 0.001 & NS \\
\hline Adjusted to $113 \mathrm{~kg}^{2}$ & 2.26 & 2.37 & 2.80 & 2.56 & 0.10 & NS & 0.001 & NS \\
\hline Loin Area $\left(\mathrm{cm}^{2}\right)$ & 36.5 & 34.5 & 36.1 & 36.8 & 1.1 & NS & NS & NS \\
\hline Adjusted to $113 \mathrm{~kg}^{2}$ & 38.1 & 36.8 & 35.9 & 36.8 & 0.9 & NS & NS & NS \\
\hline Age at Weaning & 27.3 & 27.2 & 27.3 & 27.3 & 0.4 & NS & NS & NS \\
\hline Days to Final Weight & 176.8 & 176.7 & 176.7 & 176.8 & 0.5 & NS & NS & NS \\
\hline Days to $113 \mathrm{~kg}$ & 194.3 & 203.8 & 174.9 & 176.9 & 3.5 & NS & 0.001 & NS \\
\hline Percent Lean & 50.8 & 49.9 & 48.0 & 49.2 & 0.4 & NS & 0.001 & NS \\
\hline
\end{tabular}

${ }^{1}$ Results represent data from 2 barrows and 2 gilts per litter. Abbreviations: control female, CON-F; CLA female, CLA-F; control male, CON-M; and CLA male, CLA-M.

2 Backfat thickness, loin area, days to $113 \mathrm{~kg}$ and percent lean were calculated using National Swine Improvement Federation Guidelines.

${ }^{3}$ Differences were considered significant if $P<0.05$.

acids in a diet can also influence pig growth [21], thus the increase in the amount of saturated fatty acids and the decrease in the amount of unsaturated fatty acids in sow's milk observed in this study may affect growth. Interestingly, the pigs in this study showed a significant difference in body weight on $\mathrm{d} 14$ but body weights at weaning were similar. Though not measured in this study, milk yield and milk protein content remained unchanged with CLA supplementation in dairy cattle $[8,23]$, suggesting the short term suppression of growth may be due to limited fat availability to the newborn. This may be an interesting avenue for future investigation in regards to promoting health of neonates which require artificial rearing.

At weaning, 2 barrows and 2 gilts were selected from each of 28 litters ( 15 CON, 13
CLA) and 104 of these pigs were monitored until market weight $(110 \mathrm{~kg})$. In this group of pigs, body weights at day 14 and weaning and growth rate from birth to weaning was less in pigs from sows fed CLA $(P<0.05$, Tab. VII). However, final body weight and calculated days to $113 \mathrm{~kg}$ was not different between groups. There was no effect of CLA on post-weaning growth rate or subcutaneous fat thickness or loin muscle area at the tenth rib as determined by ultrasound at $110 \mathrm{~kg}$. Expected differences between barrows and gilts were observed (not shown) including increased growth rate and carcass fat for barrows. Several studies supplementing swine diets with CLA have also shown no significant difference in average daily gain $[1,10]$, live weight, or growth rate though others have demonstrated 
improvements in body composition and feed efficiency in swine [1]. Dietary CLA affects lipid composition in several tissues $[2,27]$ while de novo lipogenesis was unaltered in pigs [2]. Dugan et al. [10] showed a reduction in subcutaneous adipose tissue and an increase in lean commercial cuts without seeing a significant difference in average daily gain, feed intake, or feed conversion efficiency. Examples of this can also be seen in humans whose diet was supplemented with CLA. Sixty-four days of supplementation resulted in no differences in fat-free mass, fat mass, percent body fat, energy expenditure, or body mass index in human subjects [34]. Mice fed CLA for four weeks and placed on control diets showed the cis-9, trans-11 CLA isomer is removed from tissue over time in a tissue specific manner and that the isomer was undetectable in liver after two weeks, fat after four weeks, and muscle after eight weeks [22]. It seems the withdrawal of CLA from these tissues also results in a loss of beneficial response since there were no significant differences in whole body fat, protein, water, or ash, two weeks after CLA was withdrawn from the diet [22]. The pigs in our study were only given CLA through weaning and failed to show any differences in body weight, backfat thickness, loin eye area, or gain:feed at the end of the study. These results suggest that exposure of the fetus to CLA during the time of fat cell differentiation had little effect on subsequent fat cell development. Combined, these studies [22, present study] suggest CLA may have long-term benefits only if maintained in the diet. Similarly, the effect of somatotropin treatment of pregnant dams on growth of the offspring is not maintained through market weight [18]. Though it may be impractical to suggest producers include CLA enhancers in diets of gestating sows in hopes of permanent benefits in body composition, these results suggest that mechanisms of CLA's actions are dependant on the continual presence of CLA in growing swine. This may be because of changes in fatty acid composition or cellular mem- brane fluidity which would be corrected once CLA is no longer present in the tissue. CLA's mechanisms of action have yet to be determined but seem to warrant continued investigation.

\section{REFERENCES}

[1] Azain M., Conjugated linoleic acid and its effects on animal products and health in single-stomached animals, Proc. Nutr. Soc. 62 (2003) 319-328.

[2] Bee G., Dietary conjugated linoleic acids affect tissue lipid composition but not de novo lipogenesis in finishing pigs, Anim. Res. 50 (2001) 383-399.

[3] Bee G., Dietary conjugated linoleic acid consumption during pregnancy and lactation influences growth and tissue composition in weaned pigs, J. Nutr. 130 (2000) 2981-2989.

[4] Brodie A., Manning V., Ferguson K., Jewell D., Hu C., Conjugated linoleic acid inhibits differentiation of pre- and post-confluent 3T3-L1 preadipocytes but inhibits cell proliferation only in preconfluent cells, J. Nutr. 129 (1999) 602-606.

[5] Brown J., Boysen M., Jensen S., Morrison R., Storkson J., Lea-Currie R., Pariza M., Mandrup S., McIntosh M., Isomer-specific regulation of metabolism and PPARgamma signaling by CLA in human preadipocytes, J. Lipid. Res. 44 (2003) 1287-1300.

[6] Brown M., Evans M., McIntosh M., Linoleic acid partially restores the triglyceride content of conjugated linoleic acid-treated cultures of 3T3-L1 preadipocytes, J. Nutr. Biochem. 12 (2001) 381-387.

[7] Chin S., Storkson J., Albright K., Cook M., Pariza M., Conjugated linoleic acid is a growth factor for rats as shown by enhanced weight gain and improved feed efficiency, $\mathrm{J}$. Nutr. 124 (1994) 2344-2349.

[8] Chouinard P., Corneau L., Barbano D., Metzger L., Bauman D., Conjugated linoleic acids alter milk fatty acid composition and inhibit milk fat secretion in dairy cows, J. Nutr. 129 (1999) 1579-1584.

[9] Demaree S., Gilbert C., Mersmann H., Smith S., Conjugated linoleic acid differentially modifies fatty acid composition in subcellular fractions of muscle and adipose tissue but not adiposity of postweaning pigs, J. Nutr. 132 (2002) 3272-3279.

[10] Dugan M., Aalhus J., Schaefer A., Kramer J., The effect of conjugated linoleic acid on fat to lean repartitioning and feed conversion in pigs, Can. J. Anim. Sci. 77 (1997) 723-725. 
[11] Fat in swine nutrition, in: Pettigrew J., Moser R. (Eds.), Swine Nutrition, Butterworth-Heinemann, Stoneham, MA, 1991.

[12] Gatlin L., See M., Larick D., Lin X., Odle J., Conjugated linoleic acid in combination with supplemental dietary fat alters pork fat quality, J. Nutr. 132 (2002) 3105-3112.

[13] Hausman G., Richardson L., Histochemical and ultrastructural analysis of developing adipocytes in the fetal pig, Acta. Anat. (Basel) 114 (1982) 228-247.

[14] Hausman G., The influence of dexamethasone and insulin on expression of CCAAT/ enhancer binding protein isoforms during preadipocyte differentiation in porcine stromal-vascular cell cultures: evidence for very early expression of C/EBPalpha, J. Anim. Sci. 78 (2000) 1227-1235.

[15] Hausman G., Wright J., Ontogeny of the response to thyroxine (T4) in the porcine fetus: interrelationships between serum T4, serum insulin-like growth factor-1 (IGF-1) and differentiation of skin and several adipose tissues, Obes. Res. 4 (1996) 283-292.

[16] Herrera E., Amusquivar E., Lipid metabolism in the fetus and the newborn, Diabetes Metab. Res. Rev. 16 (2000) 202-210.

[17] Kang K., Liu W., Albright K., Park Y., Pariza M., Trans-10,cis-12 CLA inhibits differentiation of 3T3-L1 adipocytes and decreases PPAR gamma expression, Biochem. Biophys. Res. Commun. 303 (2003) 795-799.

[18] Kelley R., Jungst S., Spencer T., Owsley W., Rahe C., Mulvaney D., Maternal treatment with somatotropin alters embryonic development and early postnatal growth of pigs, Domest. Anim. Endocrinol. 12 (1995) 83-94.

[19] McNeel R., Mersmann H., Effects of isomers of conjugated linoleic acid on porcine adipocyte growth and differentiation, J. Nutr. Biochem. 14 (2003) 266-274.

[20] National Swine Improvement Federation Guidelines [Online], available: http://mark.asci.ncsu.edu/nsif/brochure.html.

[21] O’Quinn P., Nelssen J., Goodband R., Unruh J., Woodworth J., Smith J., Tokach M., Effects of modified tall oil versus a commercial source of conjugated linoleic acid and increasing levels of modified tall oil on growth performance and carcass characteristics of growing-finishing pigs, J. Anim. Sci. 78 (2000) 2359-2368.

[22] Park Y., Albright K., Liu W., Storkson J., Cook M., Pariza M., Effect of conjugated linoleic acid on body composition in mice, Lipids 32 (1997) 853-858.

[23] Perfield J., Bernal-Santos G., Overton T., Bauman D., Effects of dietary supplementation of rumen-protected conjugated linoleic acid in dairy cows during established lactation, J. Dairy Sci. 85 (2002) 2609-2617.

[24] Poulos S., Sisk M., Hausman D., Azain M., Hausman G., Pre- and postnatal dietary conjugated linoleic acid alters adipose development, body weight gain and body composition in Sprague-Dawley rats, J. Nutr. 131 (2001) 2722-2731.

[25] Qian H., Barb C.R., Compton M.M., Hausman G.J., Azain M.J., Kraeling R.R., Baile C.A., Leptin mRNA expression and serum leptin concentrations as influenced by age, weight, and estradiol in pigs, Domest. Anim. Endocrinol. 16 (1999) 135-143.

[26] Rahman S., Wang Y., Yotsumoto H., Cha J., Han S., Inoue S., Yanagita T., Effects of conjugated linoleic acid on serum leptin concentration, body-fat accumulation, and beta-oxidation of fatty acid in OLETF rats, Nutrition 17 (2001) 385-390.

[27] Ramsay T., Evock-Clover C., Steele N., Azain M., Dietary conjugated linoleic acid alters fatty acid composition of pig skeletal muscle and fat, J. Anim. Sci. 79 (2001) 2152-2161.

[28] Rozeboom D., Pettigrew J., Moser R., Cornelius S., el Kandelgy S., In vivo estimation of body composition of mature gilts using live weight, backfat thickness, and deuterium oxide, J. Anim. Sci. 72 (1994) 355-366.

[29] Satory D., Smith S., Conjugated linoleic acid inhibits proliferation but stimulates lipid filling of murine 3T3-L1 preadipocytes, J. Nutr. 129 (1999) 92-97.

[30] Smith S., Hively T., Cortese G., Han J., Chung K., Castenada P., Gilbert C., Adams V., Mersmann H., Conjugated linoleic acid depresses the delta9 desaturase index and stearoyl coenzyme A desaturase enzyme activity in porcine subcutaneous adipose tissue, J. Anim. Sci. 80 (2002) 2110-2115.

[31] Tischendorf F., Schone F., Kirchheim U., Jahreis G., Influence of a conjugated linoleic acid mixture on growth, organ weights, carcass traits and meat quality in growing pigs, J. Anim. Physiol. Anim. Nutr. 86 (2002) $117-$ 128.

[32] Wiegand B., Sparks J., Parrish F. Jr., Zimmerman D., Duration of feeding conjugated linoleic acid influences growth performance, carcass traits, and meat quality of finishing barrows, J. Anim. Sci. 80 (2002) 637-643.

[33] Wright J., Hausman G., Adipose tissue development in the fetal pig examined using monoclonal antibodies, J. Anim. Sci. 68 (1990) 1170-1175.

[34] Zambell K., Keim N., Van Loan M., Gale B., Benito P., Kelley D., Nelson G., Conjugated linoleic acid supplementation in humans: effects on body composition and energy expenditure, Lipids 35 (2000) 777-782. 